\title{
Assessment of Surface Water Quality using Indices and Geographic Information System in the Sebou River Basin, Morocco
}

\author{
Kanga Idé Soumaila \\ Naimi Mustapha \\ Chikhaoui Mohamed
}

Soil and Water Management Laboratory, Department of Natural Resources and Environment, Hassan II Institute of Agronomy \& Veterinary Medicine,

Madinat Al Irfane, Rabat, Morocco

Doi:10.19044/esj.2021.v17n10p249

Submitted: 18 September 2020

Accepted: 23 March 2021

Published: 31 March 2021
Copyright 2021 Author(s)

Under Creative Commons BY-NC-ND

4.0 OPEN ACCESS

Cite As:

Kanga Idé S., Naimi M. \& Chikhaoui M. (2021). Assessment of Surface Water Quality using Indices and Geographic Information System in the Sebou River Basin, Morocco. European Scientific Journal, ESJ, 17(10), 249. https://doi.org/10.19044/esj.2021.v17n10p249

\section{Abstract}

The aim of this study is to access the quality of monitored rivers and to map the polluted river sections in the Sebou basin using Geographic Information System (GIS). The potential causes of water quality variation will also be added for suitable measures to be taken. A Water Quality Index (WQI) which developed in Morocco was applied to 17 river water quality monitoring stations with data on 6 parameters (Dissolved oxygen (DO), ammonium ion $\left(\mathrm{NH}_{4}{ }^{+}\right)$, 5-day biochemical oxygen demand $\left(\mathrm{BOD}_{5}\right)$, chemical oxygen demand (COD), fecal coliforms (FC) and total phosphorus (TP)) collected twice during the wet and dry season over 1990-2017 period. The result shows that river water quality is classified as bad, very bad and medium at $59 \%$ of the monitoring stations, while $41 \%$ are considered as good to excellent. Interpolation of mean values of overall WQI of the 17 river water quality monitoring stations, revealed evidence of quality degradation along several kilometers of most river sections in the Sebou basin. The correlation matrix between the sub-indices of water quality parameters and the overall WQI showed high positive correlation coefficients and highlights the contribution to water quality degradation as follows: $\mathrm{TP}(r=+0.96) \geq \mathrm{NH}_{4}^{+}(r=+0.96$ 
)$>\mathrm{BOD}_{5}(r=+0.94)>\mathrm{COD}(r=+0.86)>\mathrm{FC}(r=+0.83)>\mathrm{DO}(r=$ +0.79 ). The sections of Fès, Innaounene Rivers, and an extended stretch of Tizguit River must no longer be used for irrigation. River water quality is overall of better quality in the wet season compared to the dry season. Simple linear regressions between the seasonal water quality variation and the overall WQI showed higher coefficients of determination $\mathrm{R}^{2}(0.67$ and 0.60$)$ between dry season WQI and the overall WQI and between wet season WQI and the overall WQI respectively. It is clear that discharges of industrial and domestic wastewater during the dry season and agricultural activities are most likely to be the causes of the degradation of river water quality.

Keywords: River water, Water quality index, IDW interpolation, Pollution, Sebou river basin

\section{Introduction}

Surface water is in the forefront of global environmental change and the impacts of anthropogenic activities. It is used in several sectors, but led by agriculture (mainly irrigation and aquaculture) as well as industry, energy, domestic use, recreational water, and others (Liu \& Mao, 2020; Tian et al., 2018; Staoğlu et al., 2019; Liu et al., 2016). Throughout the world, water quality problems have been reported (Tomas et al., 2017; Kanga et al., 2019a), but the situation is yet to improve. The global population keeps increasing and socio-economic activities continue to rise, particularly intensive agriculture with the excessive use of fertilizers. Industrial activities and wastewater discharges into rivers often cause disasters to aquatic life. A mismanaged wild landfill can stand as a serious potential candidate for contributing to the pollution of surface water. As river water quality worsens, agriculture and other economic activities will be further impacted by pollution. This is because in many locations, agricultural production is directly dependent on river water supply. This creates a vicious cycle of impacts, which must be cracked at least to minimize damages to human and animal health. In parallel to these anthropogenic activities, runoff, soil erosion, and flooding (Ustaoğlu et al., 2019; Sanchez et al., 2006) introduce all kinds of pollutants into rivers deteriorating water quality for any useful purpose. Therefore, it is of utmost importance to assess rivers' water quality for drinking and farming purposes. Contaminated water can affect agricultural products and cause serious health problems for humans and animals. Recent research has shown some general interest in exploring the importance of water quality to human health as reported by Tlili-Zrelli et al. (2018). Assessing water quality helps to know the quality status of surface water in rivers as well as the potential causes of its pollution, allowing appropriate decisions for mitigating the impacts of both human activities and natural causes. In several countries of the Mediterranean 
basin, water quality is at present impaired, and Morocco is amongst the countries suffering from water scarcity and pollution. In this sense, several studies relating to water quality (Kanga et al., 2019b; Perin et al., 2014; Hayzoun et al., 2015; Essahle et al., 2010; Koukal et al., 2004) have been carried out with the aim of determining the status of surface water quality in various districts in the country, including the Sebou river basin, which is the area of interest in this study. Urban populations are growing in the Sebou river basin, while industrial activities consist of oil and paper mills, tanneries, and sugar factories. Consequently, there is an urgent need to investigate and invest in the assessment of surface water quality, as the impact of water pollution on the environment and human health is becoming more and more important. As climate conditions affect water quality in arid and semi-arid areas (Perrin et al., 2014; Hayzoun et al., 2015), spatiotemporal water quality assessment of rivers is relevant to understand the changes in quality at a given period of the year and helps decision-makers or water managers take adequate actions. The water quality is usually evaluated on its chemical, physical, and biological composition with respect to its intended use. The WQI is determined by combining one or more chemical, physical, and biological parameters into a composite numerical or categorical index. The types of parameters used are dependent on the intended use of water, national standards, and the environmental issues faced in the study area. Several WQIs have already been developed to assess the suitability of water resources depending on the intended use (Lermontov et al., 2009; Kanga et al., 2019a), as well as several surface water quality assessment studies carried out in the Sebou river basin (Perrin et al., 2014; El Ouali et al., 2011; Hamdaoui et al., 2018; Hayzoun et al., 2015). A WQI developed in Morocco was used on 17 river water quality monitoring stations with data on 6 parameters $\left(\mathrm{DO}, \mathrm{NH}_{4}{ }^{+}, \mathrm{BOD}_{5}, \mathrm{COD}, \mathrm{FC}\right.$, TP) and collected twice during the wet and dry season over the 1990-2017 period. The aim of this study is to assess the water quality of rivers in the Sebou river basin using GIS in order to identify the polluted river sections and the potential causes of water quality variation.

\section{Material and Methods Description of the Study Area}

The study was carried out in the Sebou river basin, which extends over a surface area of $40,000 \mathrm{Km}^{2}$ and comprises one of the largest basins in Morocco. With a population of 6.2 million inhabitants, the Sebou river basin is a farming area in which industrial activities provide a significant input into the national economy. According to the Sebou river basin authority, the mean annual rainfall is $640 \mathrm{~mm}$ in the basin, reaching a maximum of $1,000 \mathrm{~mm}$ in the North-East side, and minimum values ranging from 400 to $500 \mathrm{~mm}$ in the center (Fès-Meknès area). Towards the south, near the city of Ifrane, 700-900 
$\mathrm{mm}$ per year is recorded. The rainfall distribution is characterized by two seasons: the wet season from October to May, receives almost $90 \%$ of the annual rainfall, and the dry season from June to September, accumulating 10\% of the total annual rainfall. This watershed holds nearly one-third of the country's surface water resources. There are several rivers in the Sebou river basin, foremost of which is the Sebou, rising in the south part of the basin and flowing $500 \mathrm{~km}$ downstream before joining the Atlantic Ocean. The river has many tributaries of which the largest are: Beht, Fès, Rdom, Innaouene, Ouislane, Mikkes, Guigou, etc. Figure 1 illustrates the location of the basin and its geographical characteristics. Biophysically, the catchment is bounded upstream by the Rif Mountains in the North and by the Middle Atlas Mountains in the South. The plateau of Saïs is located between these two mountain ranges within the area of Fès-Meknès. In the downstream part of the catchment, towards the sea, the Sebou sub-basin consists of a large alluvial plain known as the Gharb plain. The Rif highlands are mainly characterized by impermeable Cretaceous clay-marl formations, while the Gharb plain and Saïs plateau are shaped by permeable Tertiary and Quaternary materials. The Atlas domain consists chiefly of permeable Jurassic limestones and calcareous materials from the Lias. The potential irrigated areas are estimated at 375,000 ha, of which 269,600 are currently irrigated according to the Sebou Hydraulic Basin Agency (ABHS). Industrial activities play a major economic role and the most important industrial units are: sugar factories, paper and oil mills, tanneries, cement works, and textile. 


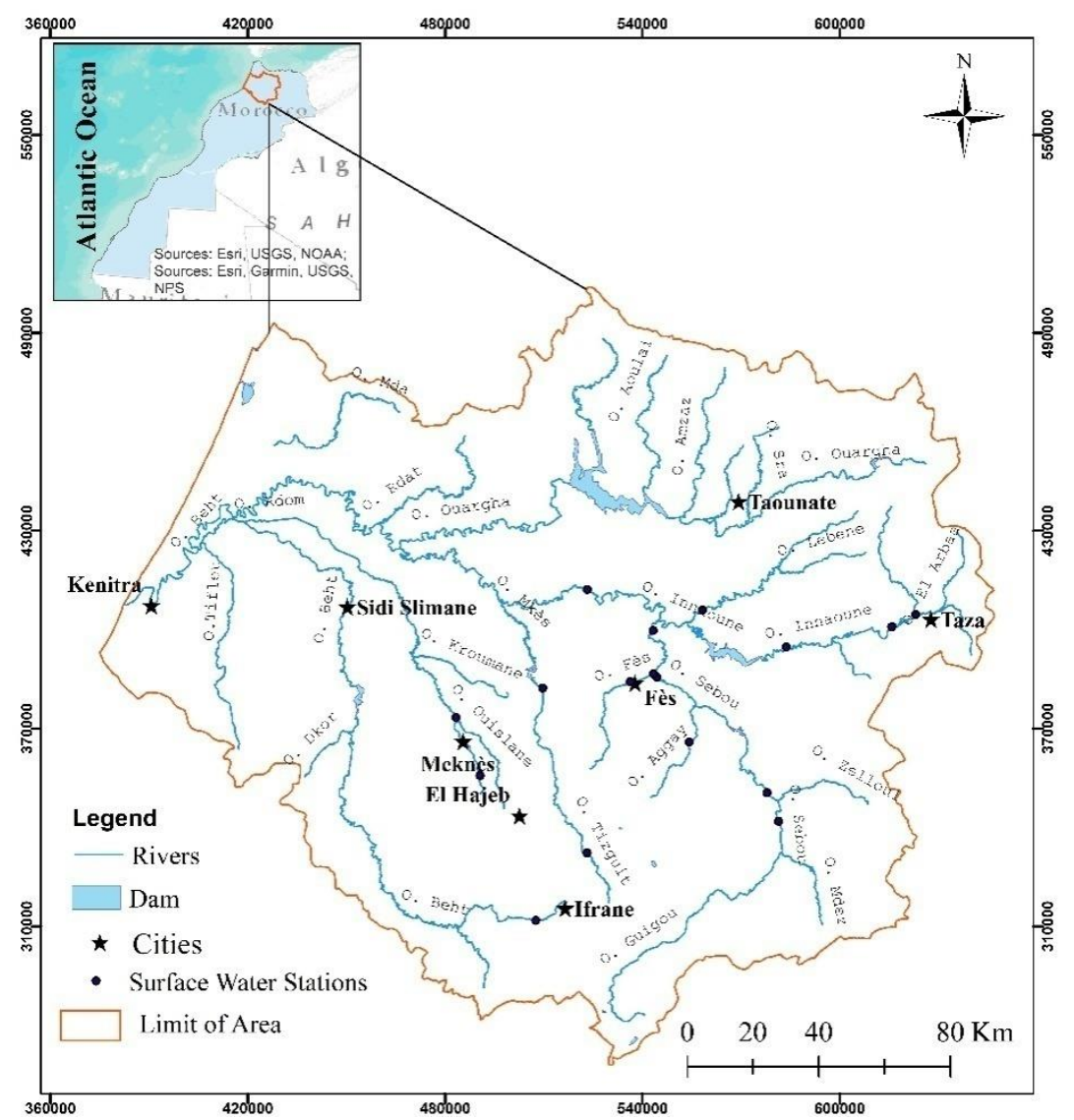

Figure 1. Geographic setting of the Sebou Basin along with the water monitoring stations

\section{Data Collection}

Twenty-seven years of water quality data from 17 river water quality monitoring stations were collected at the Sebou Hydraulic Basin Agency (ABHS), a regional water resources management body in Morocco. Table 1 shows the water quality parameters for all 17 water monitoring stations. Some of them are more ancient compared to others. Therefore, data may not consistently date back to 1990, and may show time gaps in the time series of the years. The monitoring stations are located on river banks and distributed from the center of the basin to the upstream of every few kilometers forming sections as shown in Figure 1. 
Table 1. Water quality parameters, their associated units, and data chronology

\begin{tabular}{|l|c|c|}
\hline Parameter & Unit & Data chronology \\
\hline 5-day biochemical oxygen demand $\left(\mathrm{BOD}_{5}\right)$ & $\mathrm{mg} / \mathrm{l}$ & $1990-2017$ \\
\hline Chemical oxygen demand (COD) & $\mathrm{mg} / \mathrm{l}$ & $1990-2017$ \\
\hline Ammonium $\left(\mathrm{NH}_{4}{ }^{+}\right)$ & $\mathrm{mg} / \mathrm{l}$ & $1990-2017$ \\
\hline Fecal coliforms (FC) & $\mathrm{CPU} / 100 \mathrm{ml}$ & $1990-2017$ \\
\hline Total phosphorus (TP) & $\mathrm{mg} / \mathrm{l}$ & $1990-2017$ \\
\hline Dissolved oxygen (DO) & $\mathrm{mg} / \mathrm{l}$ & $1990-2017$ \\
\hline
\end{tabular}

\section{WQI Calculation and Spatialization}

Kanga et al. (2019b) developed a WQI in Morocco, which took into account of the Moroccan water quality standards, following 3 steps: the adoption of water quality parameters, the normalization of the parameter values to obtain sub-indices, and the aggregation of the sub-indices into an overall index. Figure 2 shows the steps involved in the development of the WQI.

1. Adoption of parameters

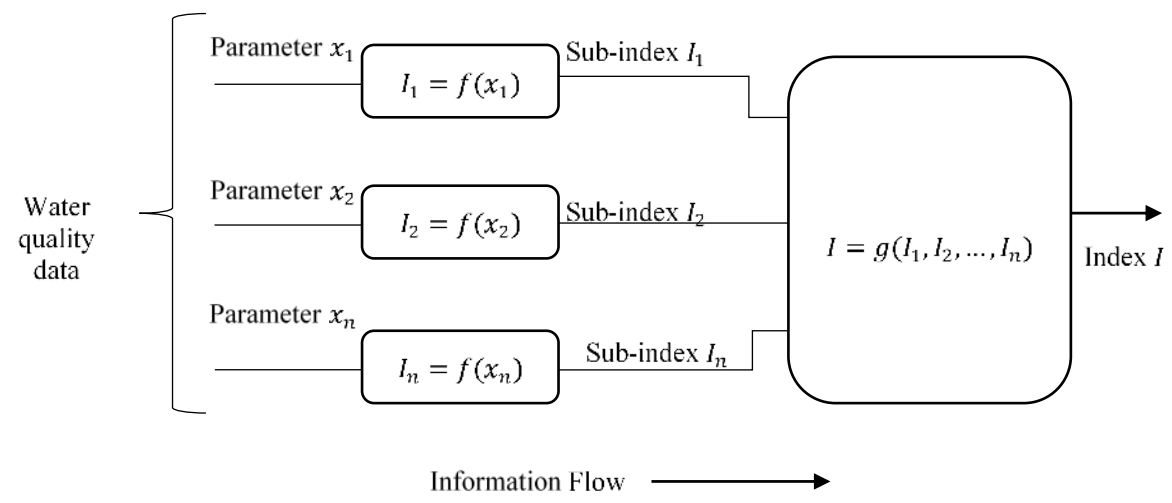

Figure 2. General steps for index development from Abbasi and Abbasi (2012)

The adoption of water quality parameters has been based upon the parameters currently used by the ABSH (Table 1). The standardization of water quality parameters was carried out using segmented linear equations for each water quality parameter based on the water quality standards prevailing in Morocco, which are comparable to the WHO standards. The general equation for normalizing a parameter is described as follows (Abbassi \& Abbassi, 2012):

$$
I_{i}=\left(x-a_{i}\right)\left(\frac{b_{i+1}-b_{i}}{a_{i+1}-a_{i}}\right)+b_{i}, a_{i} \leq x \leq a_{i+1} \text { and } b_{i} \leq \text { Classe } I \leq b_{i+1} \text {. }
$$


$I_{i}$ is the sub-index of the ith parameter, $a_{i}$ is the measured value of the ith parameter, $b_{i}$ is the ith corresponding a class according to the simplified grid of the decree 1275-02 in this context. Table 2 displays normalization functions of the parameters of water quality.

Table 2. Normalization equations of water quality parameters

\begin{tabular}{|c|c|c|}
\hline $\mathrm{NH}_{4}^{+}(\mathrm{mg} / \mathrm{l})$ & $\mathrm{TP}(\mathrm{mg} / \mathrm{l})$ & $\mathrm{FC}($ number/100 ml) \\
\hline $\begin{array}{l}I_{N H_{4}^{+}}=-100 x+100 \\
\forall 0 \leq x<0.1 \\
I_{N H_{4}^{+}}=-67.5 x+96.75 \\
\forall 0.1 \leq x \leq 0.5 \\
I_{N H_{4}^{+}}=-8.67 x+67.33 \\
\forall 0.5 \leq x \leq 2 \\
I_{N H_{4}^{+}}=-2 x+54 \\
\forall 2 \leq x \leq 8 \\
I_{N H_{4}^{+}}=0 . \forall x>8\end{array}$ & $\begin{array}{l}I_{T P}=100-100 x \\
\forall 0 \leq x<0.1 \\
I_{T P}=-135 x+103.5 \\
\forall 0.1 \leq x \leq 0.3 \\
I_{T P}=-65 x+82.5 \\
\forall 0.3 \leq x \leq 0.5 \\
I_{T P}=-4.8 x+52.4 \\
\forall 0.5 \leq x \leq 3 \\
I_{T P}=0 . \forall x>3\end{array}$ & $\begin{array}{l}I_{F C}=-0.5 x+100 \\
0 \leq x<20 \\
I_{F C}=-0.005 x+90.1 \\
20 \leq x \leq 2000 \\
I_{F C}=-0.0007 x+64.44 \\
2000 \leq x \leq 20000 \\
I_{F C}=0 . \forall x>20000\end{array}$ \\
\hline $\mathrm{DBO}_{5}(\mathrm{mg} / \mathrm{l})$ & $\mathrm{DCO}(\mathrm{mg} / \mathrm{l})$ & DO (mg/l) \\
\hline $\begin{array}{l}I_{B O D_{5}}=-3.33 x+100 \\
\forall x .0 \leq x \leq 3 \\
I_{B O D_{5}}=-13.5 x+130.5 \\
\forall x .3<x \leq 5 \\
I_{B O D_{5}}=-1.85 x+72.28 \\
\forall x .5<x \leq 10 \\
I_{B O D_{5}}=-0.8 x+58 \\
\forall x .10<x \leq 25 \\
I_{B O D_{5}}=0 . \forall x>25\end{array}$ & $\begin{array}{l}I_{C O D}=-0.5 x+100 \\
0<x \leq 20 \\
I_{C O D}=-5.4 x+198 \\
20<x \leq 25 \\
I_{C O D}=-0.86 x+84.66 \\
25<x \leq 40 \\
I_{C O D}=-0.3 x+62 \\
40<x \leq 80 \\
I_{C O D}=0 . \forall x \geq 80\end{array}$ & $\begin{array}{l}I_{O D}=11.366 x \\
\forall .0<x \leq 8.8 \\
I_{O D}=100 . \forall x>8.8\end{array}$ \\
\hline
\end{tabular}

These sub-indices were aggregated into an overall water quality index using a multiplicative and a power equation forms, as many researchers consider that geometric mean aggregation form can avert problems seen with conventional WQIs, such as eclipsing, ambiguity, compensation, etc.

$$
W Q I=\prod_{i=1}^{n}\left(I_{i}\right)^{\frac{1}{n}}
$$

Where $I_{i}$ represents the sub-index of the first parameter, $n$ is the number of parameters, and WQI is the overall water quality index.

The sub-index and overall WQI values have been categorized into 5 quality classes. Table 3 shows the range of values and their interpretations. 
Table 3. Class grouping of sub-indices and the overall water quality index

\begin{tabular}{|l|c|c|c|c|c|}
\hline Description & Very Bad & Bad & Medium & Good & Excellent \\
\hline Interval & $0-38$ & $38-50$ & $50-63$ & $63-90$ & $90-100$ \\
\hline
\end{tabular}

Using an Excel sheet, the average of the sub-indexes and the overall WQI were calculated for each station depending on the number of years sampled. Also, the average WQI per season were computed in an attempt to understanding the seasonal changes in the water quality. For each station, correlation matrices were performed between the sub-indices of the water quality parameters and the overall WQI. Under ArcGIS, data were spatialized by interpolating the average value of the sub-indexes, the overall WQI, and the seasonal WQI for all stations along the rivers using the inverse distance weighting (IDW) technique. ESRI (1992) stated that IDW provides satisfactory results when the data is uniformly distributed in an area. IDW is based on the idea by which the value of an unsampled point is the weighted average of known values of the closest neighbors, whereby the weights are inversely proportional to the distances from the prediction point to the sampled points (Muzenda et al., 2019).

\section{Results and Discussion}

Table 4 summarizes the descriptive statistics (minimum, maximum, mean and standard deviation) of sub-indices (related to each river water parameter) and the overall WQI. The minimum, maximum, and mean values of the total phosphorus sub-index for all 17 monitoring stations are 0.0 (Very Bad), 88.3 (Excellent) and 55.6 (Medium), respectively. The minimum value "0.0" of this sub-index indicates that at least for one monitoring station, the concentration of phosphorus exceeded the permissible limit (>3 mg/l) during one or more years. The sub-index for ammonium showed a minimum, maximum, and mean with values of 0.0 (very bad), 96.2 (Excellent), and 62.0 (Medium) respectively. Alike total phosphorus, the concentration of ammonium has also exceeded the tolerable upper limit for acceptable water quality at one or more monitoring stations. The fecal coliform contents resulted in sub-index values such as 0.0 (very bad), 90.2 (Excellent) and 64.6 (Medium) for minimum, maximum and mean, respectively. The permissible limit for fecal coliform content is $20,000 \mathrm{CPU} / 100 \mathrm{ml}$ in accordance with the Moroccan water quality standards for surface water. Exceeding this concentration means that the water quality is classified as very bad. The $\mathrm{BOD}_{5}$ sub-index values showed a minimum, maximum and mean value of 23.2 (Very bad), 96.5 (Excellent), and 67.9 (Good) correspondingly. When the BOD5 content exceeds $25 \mathrm{mg} / \mathrm{l}$, river water quality is classified as severely polluted according to the national standards. The minimum, maximum and mean values of the COD sub-index are 21.1 (Very bad), 96.7 (Excellent), and 66.7 (Good) 
respectively. The permissible limit of COD concentration is $80 \mathrm{mg} / \mathrm{l}$. For dissolved oxygen (DO) concentrations, the minimum, maximum, and mean values of this sub-index are 28.7 (Very bad), 97.2 (Excellent), and 72.9 (Good). The permissible limit for DO concentrations is $1 \mathrm{mg} / \mathrm{l}$.

Table 4. Descriptive statistics of sub-indices of water quality parameters

\begin{tabular}{|l|c|c|c|c|}
\hline Sub-index of Parameter & Minimum & Maximum & Mean & Standard Deviation \\
\hline TP & 0.0 & 88.3 & 55.6 & 24.5 \\
\hline FC & 0.0 & 90.2 & 64.6 & 26.3 \\
\hline $\mathrm{NH}_{4}{ }^{+}$ & 0.0 & 96.2 & 62.0 & 33.8 \\
\hline $\mathrm{BOD}_{5}$ & 23.2 & 96.5 & 67.9 & 26.7 \\
\hline COD & 21.1 & 96.7 & 66.7 & 24.7 \\
\hline DO & 28.7 & 97.2 & 72.9 & 22.0 \\
\hline WQI & 0.0 & 91.5 & 51.6 & 30.8 \\
\hline
\end{tabular}

With regard to the overall WQI, the minimum, maximum, and mean values are 0.0 (very bad), 91.5 (excellent) and 51.6 (medium), successively. Figure 3 displays the overall WQI values for each monitoring station. The result shows that the water quality of the rivers analyzed can be considered highly degraded during the 1990 to 2017 period. In fact, the river water quality is classified as "very bad to medium" at $59 \%$ of the monitoring stations, and as "good to excellent" at the remaining stations.

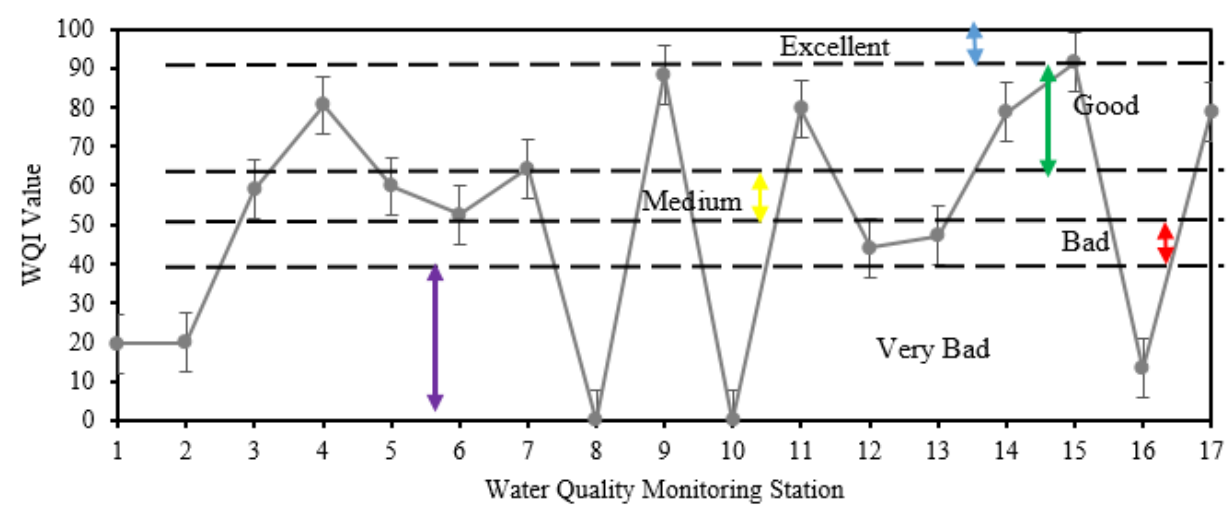

Figure 3. Variation of the overall surface water quality index for 17 monitoring stations

\section{Water Quality Parameters}

The spatial variation in surface water quality for each water quality parameter was obtained using the IDW interpolation technique based on the 17 water quality-monitoring stations. Figure 4 shows the spatial distribution of water quality parameters related to the values of their sub-index. 


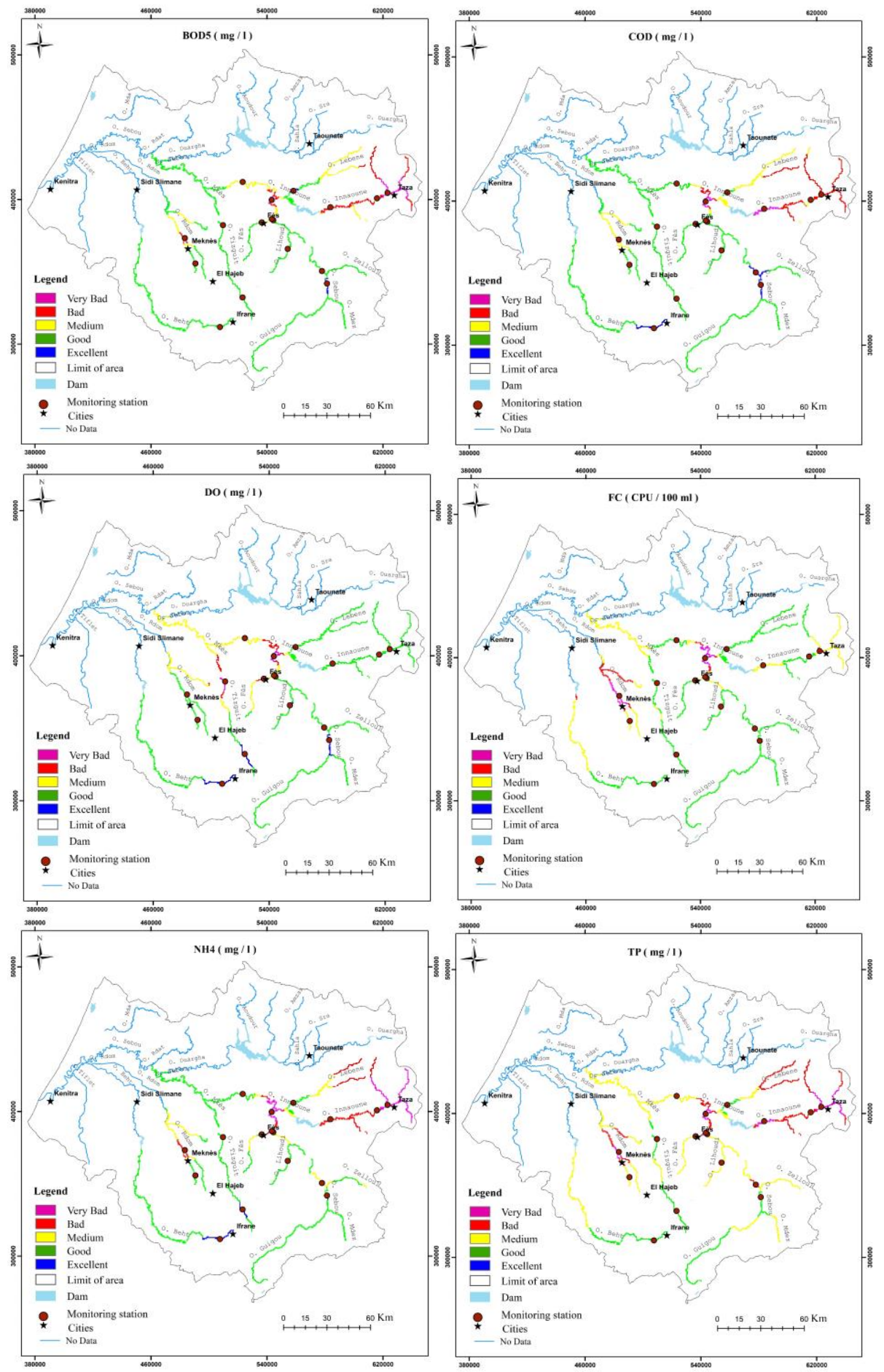

Figure 4. Spatial distribution of the sub-indices of $\mathrm{BOD}_{5}, \mathrm{COD}$, and $\mathrm{DO}, \mathrm{FC}, \mathrm{NH}_{4}{ }^{+}$and $\mathrm{TP}$ 


\section{5-day Biochemical Oxygen Demand (BOD5)}

The 5-day BOD is an indicator measuring the amount of oxygen required to biochemically degrade any organic matter, and to oxidize inorganic matter (Brandt et al., 2017). Analysis of the BOD map shows that water quality is classified as good to excellent in most sections of the rivers. Meanwhile, on Innaoune River and its tributaries, the water quality ranged from very bad to bad near the city of Taza and from medium to bad at the north of the city of Fès. The water quality of Fès River at the north of the city is classified as medium to very bad over 6 kilometers. On Rdom River, the water quality is classified as medium, very bad, and bad along a stretch of $30 \mathrm{~km}$ in the north of Meknès. In river sections where water quality is degraded, the neighboring localities are characterized by high level of economic activities, chiefly industrial that includes oil, paper and sugar mills, and tanneries. Consequently, about 3.7 million inhabitant-equivalents per year are generated and discharged into the Sebou river systems. Beware that wastewater emissions are often uncontrolled in this basin. Perrin et al. (2014) estimated that about $20 \%$ is discharged directly into rivers with no prior treatment. Essahale et al. (2010) reported a high abundance of bacterial communities in Fès River, which results from tannery wastes of the city of Fès. The 5-day BOD is a meter of the growing of bacteria and other organic and animal matters (Brandt et al., 2017; Li \& Liu, 2019).

\section{Chemical Oxygen Demand (COD)}

Chemical Oxygen Demand is an indicator that measures the amount of oxygen consumed in a solution in reaction, used to estimate the amount of oxidizable pollutants in surface water ( $\mathrm{Li} \& \mathrm{Liu}, 2019)$. Examination of the COD map shows that water quality in most rivers of the basin is classified as good to excellent. However, some stretches showed a decreasing of water quality that ranges from medium to very bad. This is the case of Innaoune River and its tributaries for which river water quality was very bad, bad and medium along an accumulated distance of $147 \mathrm{~km}$. On Fès and Sebou Rivers, water quality was very bad and medium respectively over 6 and $90 \mathrm{~km}$ north of the city of Fès. The water quality of Lebene River varied from medium to bad along a very prolonged stretch of the river. Similarly, Rdom River and its tributaries showed a water quality classified as medium. Alike $\mathrm{BOD}_{5}$, Chemical Oxygen Demand (COD) results from both industrial sources and landfill leachate. In the Sebou river basin, according to the ABHS data of 2013, 130 million $\mathrm{m}^{3}$ of wastewater are discharged yearly into rivers while 9 $375 \mathrm{t}$ of solid waste are dumped annually into the ground. 


\section{Dissolved Oxygen (DO)}

Dissolved Oxygen is an indicator measuring the amount of oxygen being dissolved in water to sustain aquatic life. It is highly dependent on water temperature. For instance, high temperature decreases the amount of dissolved oxygen (Li \& Liu, 2019). Analysis of the map portraying dissolved oxygen shows that most river water has quality ranging from good to excellent. Nevertheless, on Innaouene River and its tributaries as well as Tizguit River, water quality is classified as medium to very bad for a length of $147 \mathrm{~km}$ and $33 \mathrm{~km}$, respectively. Similarly, Fès and Sebou Rivers had very bad or bad water quality over a length of 37 and $92 \mathrm{~km}$ respectively, which means that DO is extremely low over extended segments. Many researchers (Perrin et al., 2014; Koukal et al., 2004; Hayzoun et al., 2014; El Ouali et al., 2011) reported that DO was very low in Fès River due to industrial discharges and domestic wastewater, as well as agricultural activities.

\section{Fecal Coliforms (FC)}

Fecal coliforms are signs of the presence of pathogens from human or warm-blooded animal intestines. The presence of such organisms in river water indicates fecal contamination, meaning that a potential health risk exists for anyone exposed to this water (Walker et al., 2019). Water quality associated with fecal coliforms is classified as good for most river sections. However, on some segments of Innaoune River, water quality is considered as medium or bad near the city of Taza, and very bad or bad north of the city of Fès. Water quality is classified as medium, bad and very bad on Fès River, to the north of the city, as well as on Rdom River on both sides of the city of Meknès. El Ouali et al. (2014) reported fecal coliform contamination of human and animal origins in these river sections near Meknès. Fecal coliforms arise from both domestic waste and non-point source pollution such as agriculture and confined human and animal defecation (Walker et al., 2019).

\section{Ammonium ( $\left.\mathrm{NH}^{+}{ }_{4}\right)$}

Ammonium results from the microbiological decomposition of nitrogen compounds in organic matter, which may occur naturally in water or from industrial discharges, domestic waste and animal feces (Li \& Liu, 2019). Water quality based on ammonium is classified as good to excellent on most river sections. However, the quality is bad and very bad along $5 \mathrm{~km}$ segments of Fès River and $43 \mathrm{~km}$ down Sebou River, north of the city of Fès, a few stretch of Innaoune River near the city of Taza, and over a long segment on both sides of the city of Meknès. It is considered as medium and bad on Lebene River, medium on several sections of Fès, Sebou and Rdom rivers. In Fès and Sebou rivers, Perrin et al. (2014) reported that high ammonium concentrations are explained by ammonification of nitrogen compounds in industrial 
discharges and prevailing high temperatures. El Ouali et al. (2011) estimated that high ammonium concentrations in rivers, near Meknès, are associated with landfills and agriculture, and wool cleaning for excess ammonium in Fès River. Koukal et al. (2004) reported high concentrations of ammonium in the river of Fès as well. Moreover, according to data from ABHS, roughly some 900 tons per year of nitrogen is leached away from the Sebou basin.

\section{Total Phosphorus (TP)}

Total phosphorus measures the total phosphorus constituents in water. It may result from many sources, including agricultural, industrial and domestic ones (El Ouali et al., 2011). Water quality based on total phosphorus concentrations within rivers of the Sebou basin remains of high concern. It is considered as medium, bad and very bad in almost all the rivers, except for the Guigou, Tizguit, Sebou and Beht branches, located at the farther south of the Sebou basin. Many researchers have previously reported high concentrations of total phosphorus in Fès River (El Ouali et al., 2011; Hayzoun et al., 2014). Agriculture, widely practiced alongside stretches of the rivers, increases total phosphorus pollution with almost 220 tons of phosphate leached annually according to data from the Sebou river basin Agency.

\section{Overall WQI}

Interpolation of mean overall values of WQI of the 17 monitoring stations along the rivers revealed evidence of degradation of river water quality in the Sebou river basin. Figure 5 illustrates the water quality spatialization results of rivers during the period of sampling (1990-2017). 


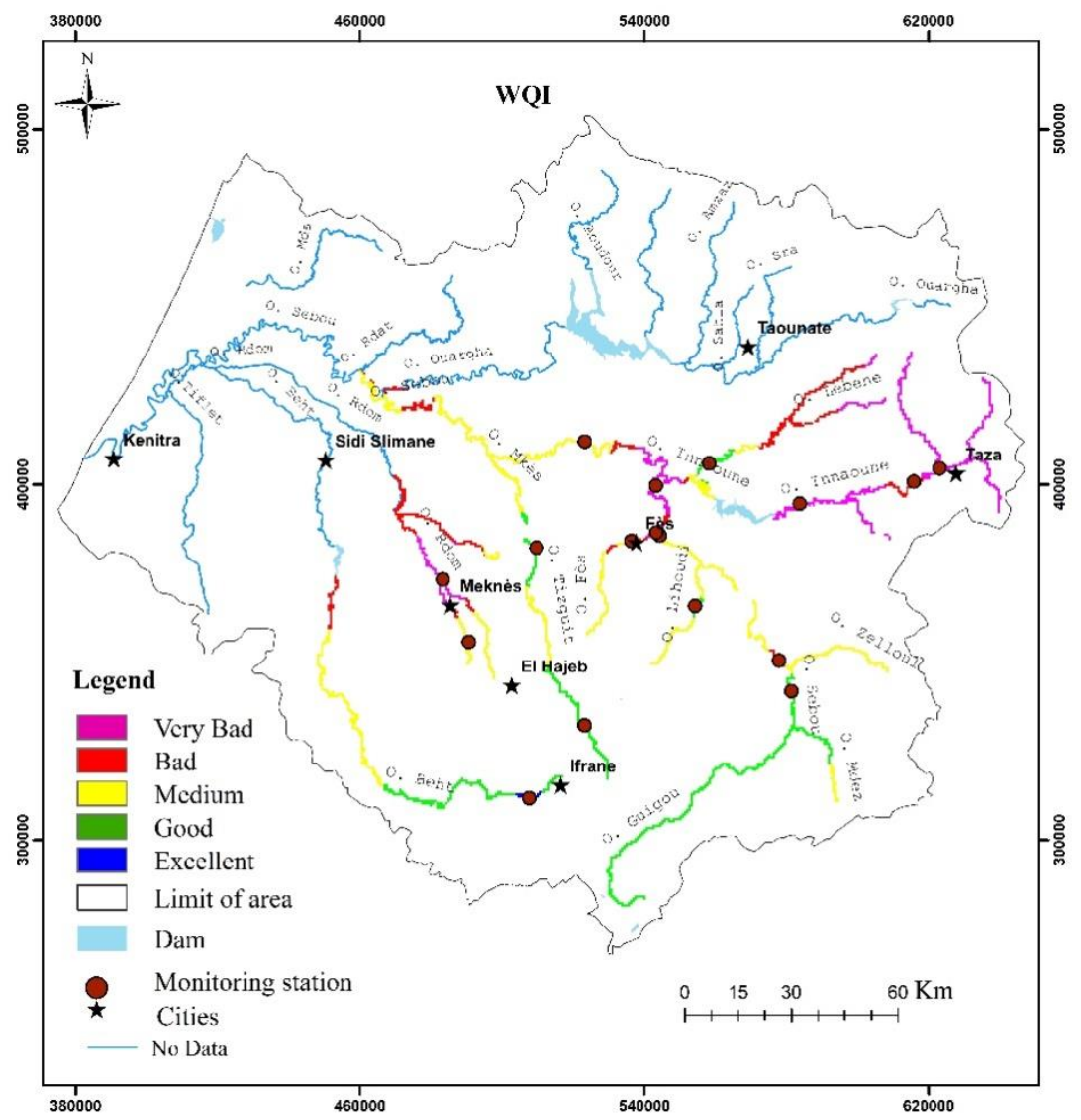

Figure 5. Overall surface water quality

Merely sections of rivers in the southern parts of the basin, which are forested, showed good or excellent water quality. The remaining river sections are highly polluted. This fact is not surprising; to tell the truth, surface water in the Sebou river basin is considered to be the most polluted in Morocco. In fact, several researchers have reported excessive pollution in many rivers, such as Fès River. Industrial and agricultural activities in concert with untreated domestic and industrial wastewater discharges have proven to be the sources of water quality deterioration in this basin (Hyazoun et al., 2015; Perrin et al., 2014; Essahle et al., 2010; Koukal et al., 2004). The correlation matrix between the values of sub-indices and the overall WQI showed high positive correlation coefficients. Table 5 displays the correlation analysis between these two variables. 
Table 5. Correlation matrix between sub-indices and the overall WQI

\begin{tabular}{|l|r|r|r|r|r|r|r|}
\hline & \multicolumn{1}{|c|}{ DO } & \multicolumn{1}{c|}{ BOD $_{5}$} & \multicolumn{1}{c|}{ COD } & $\mathrm{NH}_{4}{ }^{+}$ & TP & FC & WQI \\
\hline DO & 1 & & & & & & \\
\hline BOD $_{5}$ & 0.80 & 1.00 & & & & & \\
\hline COD & 0.68 & 0.83 & 1.00 & & & & \\
\hline $\mathrm{NH}_{4}{ }^{+}$ & 0.78 & 0.93 & 0.79 & 1.00 & & & \\
\hline TP & 0.73 & 0.89 & 0.75 & 0.92 & 1.00 & & \\
\hline FC & 0.69 & 0.74 & 0.75 & 0.77 & 0.73 & 1.00 & \\
\hline WQI & 0.79 & 0.94 & 0.86 & 0.96 & 0.96 & 0.83 & 1.00 \\
\hline
\end{tabular}

The analysis of Table 5 shows high positive correlation coefficients between variables. This means that all parameters may have come out from the identical source. The correlation coefficients are high and are rated as follow: $\mathrm{TP} \geq \mathrm{NH}_{4}{ }^{+}>\mathrm{BOD}_{5}>\mathrm{COD}>\mathrm{FC}>\mathrm{DO}$. Therefore, variations in water quality are caused by the concentrations of total phosphorus, ammonium, 5day biochemical oxygen demand, chemical oxygen demand, fecal coliform and dissolved oxygen, respectively. Similar results have been reported by some researchers (Hyazoun et al., 2015; Perrin et al., 2014; Essahle et al., 2010; Koukal et al., 2004; El Ouali et al., 2011; Hamdaoui et al., 2018) who estimated that, in an undefined ranking, the concentrations of $\mathrm{NH}_{4}^{+}, \mathrm{TP}, \mathrm{COD}$, $\mathrm{DO}, \mathrm{FC}$, and $\mathrm{BOD}_{5}$ are the main causes of the degradation of river water quality in the Sebou basin.

\section{Spatial-Seasonal Variation of River Water Quality}

WQI mean values for each season (1990-2017) were computed for each river water quality monitoring station of the 17 sampled. The wet season includes samples collected from October to May (about $90 \%$ of total annual rainfall), and the dry season includes samples collected from June to September (about $10 \%$ of total annual rainfall). Figure 6 displays water quality indices of the rivers in dry and wet seasons and the overall WQI (no distinction of seasons). 


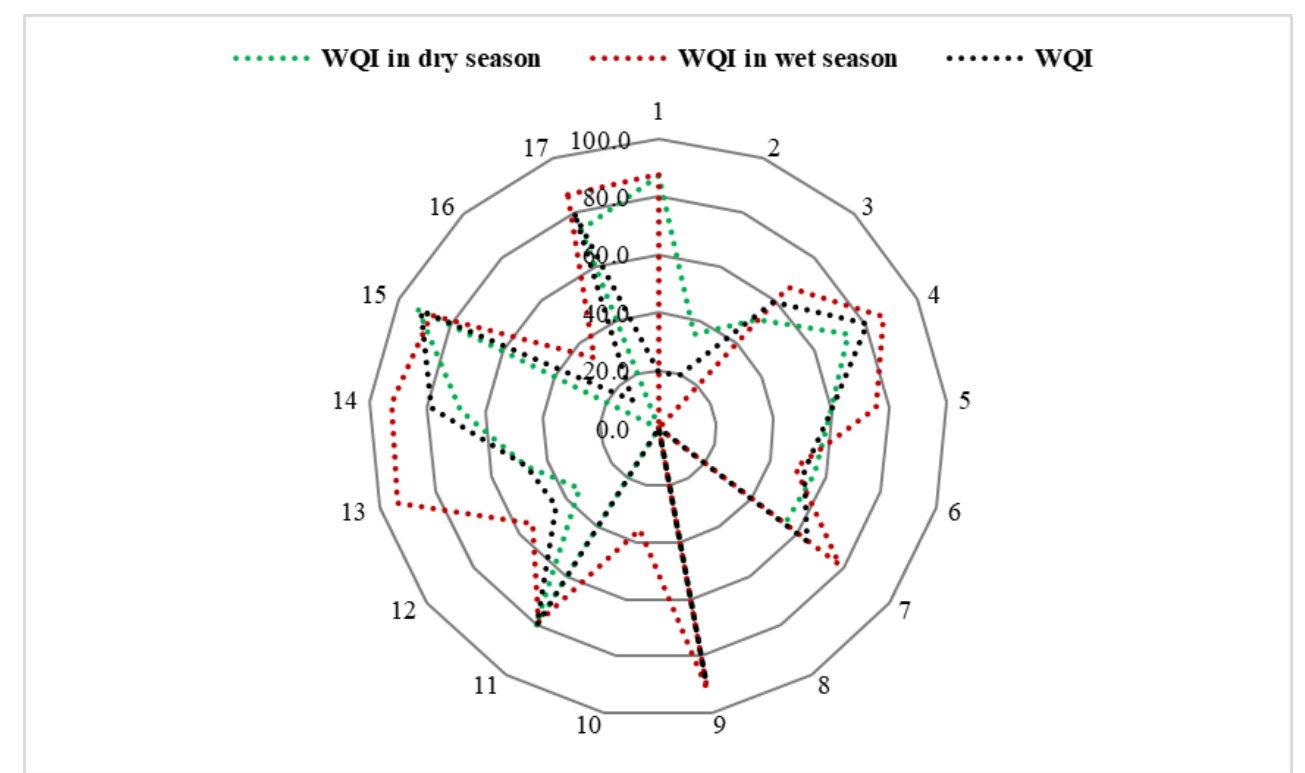

Figure 6. River water quality indices in dry season, wet season, and the overall WQI

The water quality of the rivers has varied seasonally, and the quality is commonly better during the wet season. Rising water levels after rainfall events dilute pollutant concentrations. It must be assumed that despite the input of several pollutants during runoff, the dilution effect of pollutant concentrations is more marked rather than the cumulative effect of pollutant concentrations. During the dry season, water quality is severely damaged. Figure 7 shows the spatial and temporal variation of river water quality in the Sebou basin. The analysis of the map of dry season WQI shows that all the river stretches have severely degraded water quality. It varies from medium to very bad in almost all rivers. Only sections of few kilometers $(154 \mathrm{Km}$ for all rivers sections) in the southern-forested areas showed water of good and excellent quality, particularly on Tizguit River (south of the town of El Hajeb), Beht River, and Guigou River. In contrast, observation of the wet season WQI map shows river water quality that varies from good to excellent in most rivers. 

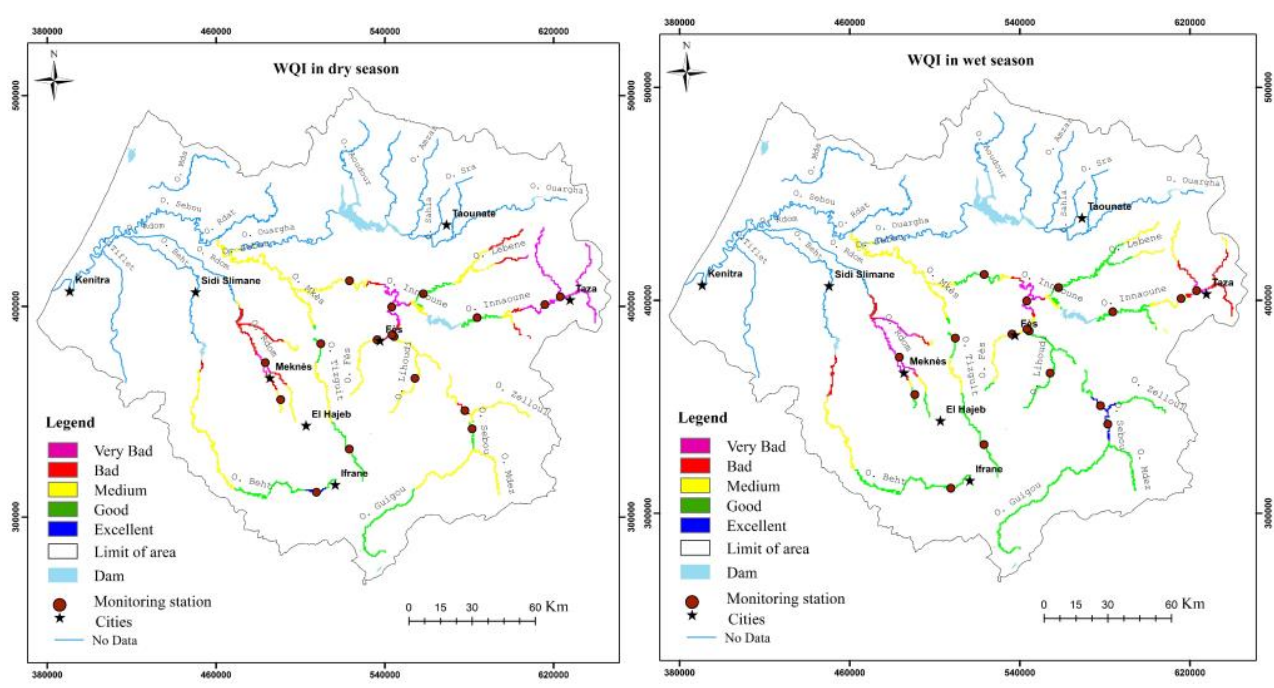

Figure 7. Seasonal variation of WQI of rivers

The linear regression plots established between the seasonal WQI and the overall WQI show high coefficients of determination (Figure 8). $\mathrm{R}^{2}$ was slightly higher between the WQI in dry season and the overall WQI and was $\mathrm{R}^{2}=0.67$, whereas it is 0.60 for the WQI in wet season with overall WQI. Hence, the overall WQI is slightly more impacted by samplings in dry season compared to those of the wet season. The correlation coefficients of the subindices of the water quality parameters and WQI in wet season are found to decrease as follows: $\mathrm{DCO}>\mathrm{FC}>\mathrm{NH}_{4}{ }^{+}>\mathrm{DO} \geq \mathrm{TP}>\mathrm{BOD}_{5}$. Whereas in dry season, the correlation coefficients between the sub-indices of the parameters and the QWI are ranked in this fashion: $\mathrm{TP} \geq \mathrm{NH}_{4}^{+}>\mathrm{BOD}_{5}>\mathrm{DCO}>\mathrm{FC}>$ DO. Agricultural activities in the Sebou basin are highly intensive in the wet season as well as in the dry season thanks to irrigation. Based on the ABHS's data, some 224,722 T/year of nitrogen components are consumed as fertilizers and about 117,000 T/year of phosphorus components are applied in the Sebou basin. The pollutant load resulting from industrial wastewater discharges reaches 29,960 T/year with chiefly COD and $\mathrm{BOD}_{5}$. 


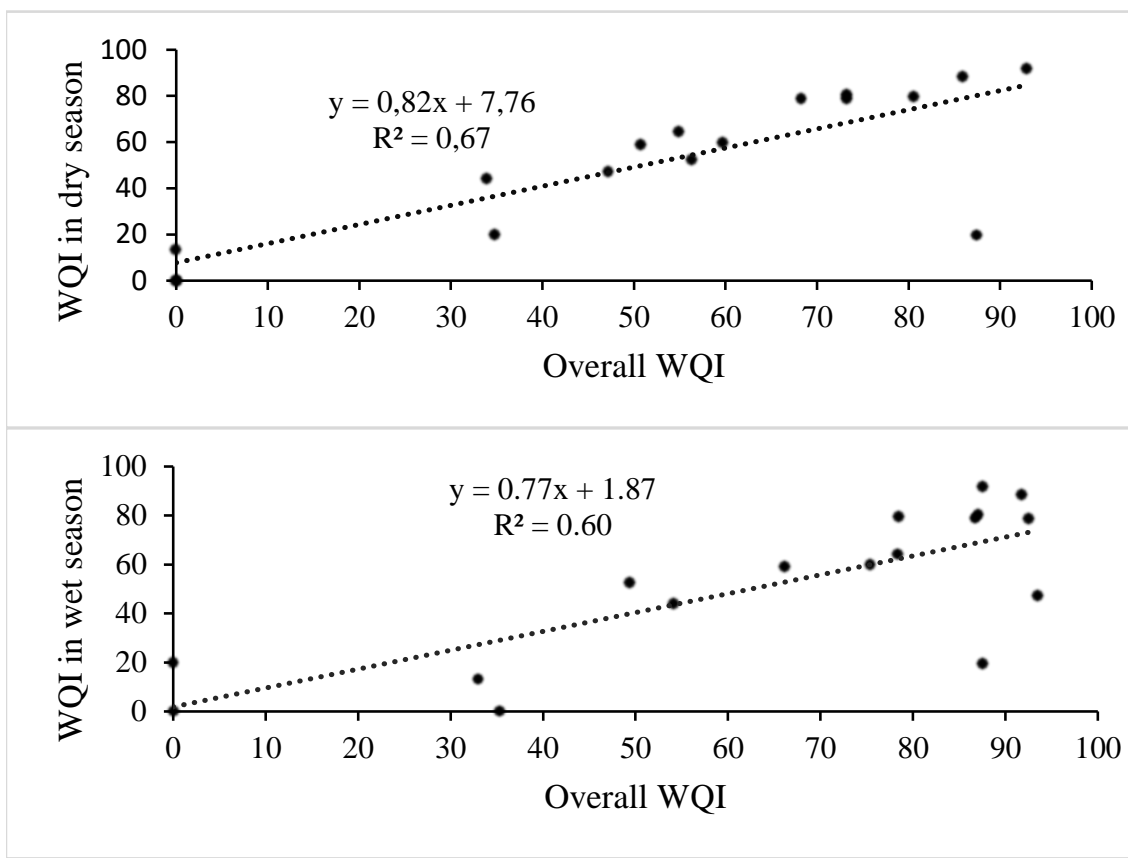

Figure 8. Linear regression between the overall WQI and the seasonal QWI variation

\section{Conclusion}

The Sebou river basin provides a high potential of surface water supply. The result of water quality assessment suggest urgent action to be taken by the authorities as $59 \%$ of the water quality monitoring stations are classified as being in an advanced stage of degradation. River water quality tends to be improved in the wet season compared to the dry season. Several sections of rivers such as Rdom on either side of the city of Meknès, Fès (north of the city of Fès) and Innaoune cannot be used for human or animal consumption without cutting-edge treatment. Unusual amounts of fecal coliforms, $\mathrm{COD}, \mathrm{BOD}_{5}, \mathrm{TP}$ and $\mathrm{NH}_{4}{ }^{+}$in rivers all year long can cause a potential health risk, if the authorities are not making appropriate management decisions as these river waters are regularly used in irrigation. Some organic pollutants or bacteria can accumulate in crops, and therefore will affect human and animal health. It is obvious that point source pollution such as discharges of domestic and industrial wastewater and non-point source pollution (intensive agriculture and others) are causing the deterioration of water quality in the rivers of the Sebou basin. We acknowledge that industrial wastewater discharges and agricultural activities are most likely to be the causes of the degradation of river water quality. 


\section{Acknowledgment}

We would like to thank the staff of the Water Quality Service of the Sebou Hydraulic Basin Agency. We would also like to thank the staff of the Soil and Water Conservation Laboratory-IAV Hassan II and GISEC project as well as the Hassan II Academy of Science and Technology for their multifaceted financial support.

Conflict of Interest: The authors declare no competing interests.

\section{References:}

1. Abbasi, T. \& Abbasi, SA. (2012). Water Quality Indices. Elsevier. Amsterdam, Netherlands. DOI: 10.1016/B978-0-444-54304-2.000014.

2. Brandt, M.J., Johnson, K.M., Elphinston, A.J., \& Ratnayaka, D.D. (2016). Chemistry, Microbiology and Biology of Water in Brandt M.J, Johnson K.M., Elphinston A.J., Ratnayaka D.D., 2016. Twort's Water Supply 7th Edition. Elsevier. Amsterdam, Netherlands. pp.235-321.

3. El Ouali, L. A., Merzouki, M., El Hillali, O., Maniar, S., \& Ibnsouda, K.S. (2011). Pollution des eaux de surface de la ville de Fès au Maroc : typologie, origine et conséquences. Larhyss Journal, 09 (2011), 55-72.

4. Essahale, A., Malki, M., Marin, I., \& Moumni, M. (2010). Bacterial diversity in Fez tanneries and Morocco's Binlamdoune River, using 16S RNA gene based fingerprinting. Journal of Environmental Sciences, 22(12), 1944-1953. https://doi.org/10.1016/S10010742(09)60344-20.

5. ESRI (1992). ARC/INFO user's guide: cell-based modelling with GRID. Analysis, display and management, 2nd ed.

6. Hamdaoui, F., Elbourkadi, A., Sibari, M., Tabti, S., Ztit, G., Saadaoui, H., Alibrahmi, E., Elkharrim, K., Belghyti, D., \& Lotfi, N. (2018). Physical and chemical monitoring of the waters pollution of the lower Sebou, Gharb, Morocco. JOWSET, 01 (03) 291-298.

7. Hayzoun, H., Garnier, C., Durrieu, G., Lenoble, V., Le Poupon, C., Angeletti, B., Ouammou, A., \& Mounier, S. (2015). Organic carbon, and major and trace element dynamic and fate in a large river subjected to poorly-regulated urban and industrial pressures (Sebou River, Morocco). Sci. Total Environ.502 (2015) 296-308. https://doi.org/10.1016/j.scitotenv.2014.09.014.

8. Kanga, I.S., Niandou, A.S., Naimi, M., Chikhaoui, M., Schimmel, K., \& Luster-Teasley, S. (2019a). A Systematic Review and MetaAnalysis of Water Quality Indices. JAST-B. 9 (2):1-14. DOI:10.17265/2161-6264/2019.01.001. 
9. Kanga, I.S., Chikhaoui, M., \& Naimi, M. (2019b).Water Quality Assessment Using a New Proposed Water Quality Index: A Case Study from Morocco. J.Environ. Agric. Biotech. 4(4):957-792. http://dx.doi.org/10.22161/ijeab.4411.

10. Koukal, B., Dominika, J., Vignati, D., Arpagaus, P., Santiago, S., Ouddane, B., \& Benaabidate, L. (2004). Assessment of water quality and toxicity of polluted Rivers Fez and Sebou in the region of Fez (Morocco). Environ Pollut, 131 (2004) 163-172. https://doi.org/10.1016/j.envpol.2004.01.014.

11. Lermontov, A., Yokoyama, L., Lermontov, M., \& Machado, M.A.S., (2009). River quality analysis using fuzzy water quality index: Ribeira do Iguape river watershed, Brazil. Ecol. Indic, 9 (2009), 1188-1197. https://doi.org/10.1016/j.ecolind.2009.02.006.

12. Li, D. \& Liu, S. (2019). Detection of River Water Quality in Li D., Liu S., (2019). Water Quality Monitoring and Management, Elsevier. Amsterdam, Netherlands. pp 211-220. https://doi.org/10.1016/B978-0-12-811330-1.00007-7.

13. Liu, Y. \& Mao, D. (2020). Integrated assessment of water quality characteristics and ecological compensation in the Xiang jiang River, south-central China. Ecol. Indic, 110 (2020) 105922. https://doi.org/10.1016/j.ecolind.2019.105922 .

14. Liu, J., Zhang, X., Xia, J., Wu, S., She, D., \& Zou, L. (2016). Characterizing and explaining spatio-temporal variation of water quality in a highly disturbed river by multi-statistical techniques. Springer Plus (2016) 5-1171. DOI 10.1186/s40064-016-2815-z.

15. Muzenda, F., Masocha, M., \& Misi, S.N. (2019). Groundwater quality assessment using a water quality index and GIS: A case of Ushewokunze Settlement, Harare, Zimbabwe. Phys Chem Earth. 112 (2019) 134-140. https://doi.org/10.1016/j.pce.2019.02.011.

16. Perrin, J.L., Raïs, N., Chahinian, N., Moulin, P., \& Ijjaali, M. (2014). Water quality assessment of highly polluted rivers in a semi-arid Mediterranean zone Oued Fez and Sebou River (Morocco). J Hydrol. 510 (2014) 26-34. https://doi.org/10.1016/j.jhydrol.2013.12.002.

17. Sa'nchez, E., Colmenarejo, M.F., Vicente, J., Rubio, A., Garci'a, M.G., Travieso, L., \& Borja, R. (2007). Use of the water quality index and dissolved oxygen deficit as simple indicators of watersheds pollution. Ecol. Indic, 7(2007)315-328. https://doi.org/10.1016/j.ecolind.2006.02.005.

18. Tian, Y., Jiang, Y., Liu, Q., Dong, M., Xu, D., Liu, Y., \& Xu, X. (2018). Using a water quality index to assess the water quality of the upper and middle streams of the Luanhe River, northern China. ). 
Sci. Total Environ. $667 \quad$ (2019) 142-151. https://doi.org/10.1016/j.scitotenv.2019.02.356.

19. Tomas, D., Curlin, M., \& Marić, A.S. (2017). Assessing the surface water status in Pannonian ecoregion by the water quality index model. Ecol. $\quad$ Indic, $79 \quad$ (2017) 182-190. http://dx.doi.org/10.1016/j.ecolind.2017.04.033.

20. Tlili-Zrelli, B., Gueddari, M., \& Bouhlila, R. (2018). Spatial and Temporal Variations of Water Quality of Mateur Aquifer (Northeastern Tunisia): Suitability for Irrigation and Drinking Purposes. Hindawi Journal of Chemistry. (2018)15. https://doi.org/10.1155/2018/2408632.

21. Ustaoğlu, F., Tepe, Y., \& Taş, B. (2019). Assessment of stream quality and health risk in a subtropical Turkey river system: A combined approach using statistical analysis and water quality index. Ecol. Indic, 113 (2020) 105815. https://doi.org/10.1016/j.ecolind.2019.105815.

22. Walker, D.B., Baumgartner, D. J., Gerba, C. P., \& Fitzsimmons, K. (2019). Surface Water Pollution in Brusseau M. L., Pepper I.L., Gerba C.P., 2019. Environmental and Pollution Science. 3rd Edition. Elsevier. Amsterdam, Netherlands. pp261-292. doi:10.1016/b978-012-814719-1.00016-1. 